\title{
PCR TECHNIQUE FOR DETECTION OF SOME VIRULENCE ASSOCIATED GENES IN LISTERIA MONOCYTOGENES ISOLATED FROM TABLE EGGS AND CLINICAL HUMAN SAMPLES
}

\author{
EMAN M. SHAKER ${ }^{*}$ and ALSHIMAA A. HASSANIEN ${ }^{* *}$ \\ *Departement of Food Hygiene, Faculty of Veterinary Medicine, Sohag University, Egypt. \\ ***Departement of Zoonoses, Faculty of Veterinary Medicine, Sohag University, Egypt.
}

Email: hassanien2008@yahoo.com

\section{ABSTRACT}

Received at: 31/12/2014

Accepted: 15/2/2015
The aim of this study was to assess the extent of Listeria monocytogenes in table eggs and its causation of human spontaneous abortions in Sohag city, Egypt by isolation methods and PCR analysis for the presence of virulence-associated genes. The result revealed that out of 30 pooled egg samples, 4 (13.3\%) L. monocytogenes were isolated from egg shells only, among which $100 \%$ and $50 \%$ were revealed to encode $i n l A$ and $h l y A$ virulence genes respectively, while recovered 5 (4.2\%) $L$. monocytogenes strains from clinical human samples, among which each of inlA and $h l y A$ virulence genes were present in $2(40 \%)$ of the isolated strains. The results give a spotlight on the association between $L$. monocytogenes from food and some virulence genes with human abortion in Sohag city.

Key words: Virulence genes, Listeria monocytogenes, Table eggs.

\section{INTRODUCTION}

Listeria monocytogenes is a food borne pathogen causing listeriosis for human, due to its evidence in raw and ready to-eat (RTE) food products which are stored at refrigeration temperatures (Filiousis et al., 2009; Pesavento et al., 2010 and Shi et al., 2015). Moreover, there have been several sporadic and epidemic outbreaks worldwide implicating L. monocytogenes contaminated foods (Ryser and Marth, 2007). L. monocytogenes is ubiquitous in nature; it can survive under conditions of high salt and low $\mathrm{pH}$. Because it can grow even at low temperatures, it can be found in many kinds of foods during storage (Ivanek et al., 2006). Ingestion of $L$. monocytogenes contaminated foods is associated with central nervous system (CNS) diseases, sepsis, endocarditis, focal infections, gastroenteritis, still births and abortions (Zhou and Jiao, 2004). The more severe form of listeriosis is invasive listeriosis with infections commonly occurring in vulnerable individuals like newborns, the elderly, immune suppressed patients and pregnant women (Rocourt et al., 2000 and Hof, 2003). However, the degree of severity is dependent on the immunity of the infected individuals and the strain itself. Although listeriosis infections are rare, the fatality rate is as high as $20 \%$ 30\% annually (Allerberger, 2003; Yucel et al., 2005 and Jeyaletchumi et al., 2010). So, protective measures, such as the development of a surveillance and detection system concerning food safety are fundamental to ensure that raw and processed foods of animal origin as table eggs are safe for human consumption. Table eggs are one of the few foods that are used among the popular dishes consumed by the people at home, restaurants, and convenience stores in their natural states without artificial additives. Most freshly laid eggs are sterile, at least from inside in case of good flock management and absence of vertical transmission also by the presence of cuticle, shell membranes and the antimicrobial properties of eggs (Sayed et al., 2009). But eggs may constitute a public health hazard, if contaminated with pathogens.

The traditional method for detecting this food-borne pathogen is time consuming; consisting of enrichment steps, plating on selective media and incubation for a period of time. Nowadays, molecular method by PCR has been so far the most extensively employed in various studies because it is a rapid procedure with both sensitivity and specificity for quick detection and identification of specific pathogenic bacteria from different sources (Sayed et al., 2009; Dharmendra et al., 2013 and Jamali et al., 2013). Multiple key virulence factors such as internalin 
(inlA), listeriolysin (hlyA), phosphatidylinositol phospholipase $\mathrm{C}(p l c A)$, actin polymerization protein $(a c t A)$ and invasive associated protein (iap) are important in L. monocytogenes pathogenesis (Furrer et al., 1991 and Portnoy et al., 1992). Therefore, detection of just one virulence associated gene by PCR is not always sufficient to identify $L$. monocytogenes (Nishibori et al., 1995). In addition, it is plausible that some L. monocytogenes strain may lack one or more virulence determinants because of spontaneous mutations (Cooray et al., 1994).

There is no official data on food poisoning/infection caused by L. monocytogenes in Egypt because $L$. monocytogenes is rarely tested in the food poisoning/infection cases. Nonetheless, the recent outbreaks of food borne listeriosis in USA and other countries and the high prevalence of $L$. monocytogenes in local foods (Jamali et al., 2013) must draw the attention of local authorities on the possible widespread of $L$. monocytogenes in the country. In the present study, our goal was to put our hands on the incidence and the relation of $L$. monocytogenes in table eggs from local markets in Sohag city with spontaneous abortions in women, and to decipher the role of internalin (inlA) and listeriolysin $(h l y A)$ in human listeriosis and to determine whether it could be used as readily assayable biomarkers to assess the pathogenic potential of strains that contaminate the food supply.

\section{MATERIALS and METHODS}

\section{Samples:}

1. Egg samples: Ninety fresh table eggs were collected during 2014 randomly from different markets in Sohag city, Egypt. Every three eggs from each market were represented as one egg pooled sample. All 30 pooled samples were examined for the incidence of L. monocytogenes in their shells and contents. Egg shells were tested by surface rinse method as described by Moats (1980) then egg contents were prepared and evacuated according to Speck (1976).

2. Human samples: a sum of 120 human samples including amniotic fluid (30), vaginal swabs (30), stool (30) and urine (30) were collected from 30 patients with a history of spontaneous abortions during second and third trimester of pregnancy. The samples were collected during 2014 from private and governmental hospitals in Sohag city, Egypt.

\section{Microbiological analysis for Listeria isolation:}

The ISO 11290 method was used for isolation and identification of L. monocytogenes in this study as described by Becker et al. (2006), as the first enrichment was done by using half Fraser broth which followed by second enrichment on Fraser broth followed by isolation on Oxford agar plates (Curtis et al., 1989). Identification was performed according to FDA bacteriological analytical manual (Hitchins, 1995).

\section{Genomic DNA extraction:}

Listeria monocytogenes strains were grown overnight at $30^{\circ} \mathrm{C}$ onto HIBYE (Heart Infusion broth containing $0.5 \%$ of Yeast Extract), for sensitivity of PCR detection an overnight culture of L. monocytogenes was centrifuged at $12000 \mathrm{rpm}$ for $10 \mathrm{~min}$, washed once in phosphate buffered saline (PBS). From this suspension, $5 \mu \mathrm{l}$ aliquot was directly used as a template for PCR amplification (Almeida and Almeida, 2000).

\section{Detection of virulence genes:}

The presence of internalin gene (inlA) was determined by PCR technique described by Almeida and Almeida (2000). PCR was performed in a reaction volume of $25 \mu \mathrm{l}$ containing $10 \mathrm{x}$ PCR buffer [100 $\mu \mathrm{M}$ Tris (pH 9.0), $500 \mu \mathrm{M} \mathrm{KCl,} 15 \mu \mathrm{M} \mathrm{MgCl}_{2}$, $0.1 \%$ gelatin] (Fermentas), $2 \mu \mathrm{M} \mathrm{MgCl}_{2}, 0.2 \mu \mathrm{M}$ dNTPs, 40 pmol of inlA, $1 \mathrm{U}$ of Taq DNA polymerase (Fermentas) and $3 \mu$ l of DNA template (50 $\mu \mathrm{g} / \mathrm{ml}$ ) under the following cyclic conditions: initial denaturation at $94{ }^{\circ} \mathrm{C}$ for $2 \mathrm{~min}, 30$ cycles in sequence $94{ }^{\circ} \mathrm{C}$ for $20 \mathrm{~s}, 55^{\circ} \mathrm{C}$ for $20 \mathrm{~s}$ and $72{ }^{\circ} \mathrm{C}$ for $50 \mathrm{~s}$, and final extension at $72{ }^{\circ} \mathrm{C}$ for $2 \mathrm{~min}$. The PCR technique described by Notermans et al. (1991) and subsequently modified by Kaur et al. (2007) was also used to detect hlyA gene. PCR was performed in $25 \mu \mathrm{l}$ reaction mixture consisting of $10 x$ PCR buffer (Fermentas), $2 \mu \mathrm{M} \mathrm{MgCl}_{2}, 0.2 \mu \mathrm{M}$ dNTPs, $0.1 \mu \mathrm{M}$ of forward and reverse primers of hlyA gene, 1.5 U Taq DNA polymerase (Fermentas) and $3 \mu \mathrm{l}$ of DNA template $(50 \mathrm{ng} / \mu \mathrm{l})$ under the following cyclic conditions: initial denaturation at $95{ }^{\circ} \mathrm{C}$ for $2 \mathrm{~min}, 35$ cycles in sequence $95{ }^{\circ} \mathrm{C}$ for $15 \mathrm{~s}, 60{ }^{\circ} \mathrm{C}$ for $30 \mathrm{~s}$ and $72^{\circ} \mathrm{C}$ for $90 \mathrm{~s}$, and final extension at $72{ }^{\circ} \mathrm{C}$ for 10 min. The PCR products were analyzed by $1.5 \%$ agarose gel electrophoresis, stained with ethidium bromide, visualized by UV transilluminator and photographed. The details of oligonucleotide sequences (Pharmacia Biotech), used in this study are shown in the following table: 
Assiut Vet. Med. J. Vol. 61 No. 144 January 2015

Sequences of primers used for detection of inlA and hylA virulence genes by PCR

\begin{tabular}{|c|c|c|c|}
\hline Target gene & Primer sequence $\left(5^{`} \rightarrow 3^{`}\right)$ & Amplicon size (bp) & Reference \\
\hline inlA & $\begin{array}{l}\text { 5`- AGCCACTTAAGGCAAT- 3` } \\
\text { 5`- AGTTGATGTTGTGTTAGA- 3` }\end{array}$ & 760 & $\begin{array}{c}\text { Almeida and } \\
\text { Almeida (2000) }\end{array}$ \\
\hline hylA & $\begin{array}{l}\text { 5`- GCAGTTGCAAGCGCTTGGAGTGAA-3 } \\
\text { 5'- GCAACGTATCCTCCAGAGTGATCG- 3` }\end{array}$ & 456 & Kaur et al.( 2007) \\
\hline
\end{tabular}

RESULTS

Table 1: Incidence of L. monocytogenes in table eggs samples using biochemical methods.

\begin{tabular}{ccccccc}
\hline & \multicolumn{9}{c}{ Table eggs } \\
\cline { 2 - 7 } Positive samples & \multicolumn{2}{c}{ Egg contents } & \multicolumn{2}{c}{ Egg shells } & \multicolumn{2}{c}{ Total } \\
\cline { 2 - 7 } & No./30 & $\%$ & No./30 & $\%$ & No./30 & $\%$ \\
\hline L. monocytogenes & 0 & 0 & 4 & 13.3 & 4 & 13.3 \\
\hline
\end{tabular}

Table 2: Incidence of L. monocytogenes in human samples using biochemical methods.

\begin{tabular}{lcccccccccc}
\hline & \multicolumn{1}{c}{ Human Samples } \\
Positive samples & \multicolumn{1}{c}{ Amniotic fluids } & Vaginal swabs & Urine & Stool & \multicolumn{2}{c}{ Total } \\
\cline { 2 - 11 } & No./30 & $\%$ & No./30 & $\%$ & No./30 & $\%$ & No./30 & $\%$ & No./120 & $\%$ \\
\cline { 2 - 11 } L. monocytogenes & 2 & 6.6 & 2 & 6.6 & 1 & 3.3 & - & - & 5 & 4.2 \\
\hline
\end{tabular}

Table 3: Pathogenicity and PCR profiles of L. monocytogenes isolates from table eggs and human.

\begin{tabular}{|c|c|c|c|c|c|c|c|c|c|c|c|}
\hline \multirow{3}{*}{ Virulence genes } & \multicolumn{5}{|c|}{ Egg shells isolates } & \multicolumn{6}{|c|}{ Human isolates } \\
\hline & \multirow{2}{*}{1} & \multirow{2}{*}{2} & \multirow{2}{*}{3} & \multirow{2}{*}{4} & \multirow{2}{*}{$\begin{array}{c}\text { Total } \\
\%\end{array}$} & \multicolumn{2}{|c|}{$\begin{array}{l}\text { Amniotic } \\
\text { fluid }\end{array}$} & \multicolumn{2}{|c|}{$\begin{array}{c}\text { Vaginal } \\
\text { swab }\end{array}$} & \multirow{2}{*}{$\begin{array}{c}\text { Urine } \\
\mathrm{P} 2\end{array}$} & \multirow{2}{*}{$\begin{array}{c}\text { Tota } \\
\%\end{array}$} \\
\hline & & & & & & $\mathrm{P} 1$ & P2 & $\mathrm{P} 1$ & $\mathrm{P} 2$ & & \\
\hline inlA & $+\mathrm{ve}$ & $+\mathrm{ve}$ & $+\mathrm{ve}$ & $+\mathrm{ve}$ & $100 \%$ & $+\mathrm{ve}$ & -ve & $+\mathrm{ve}$ & $-\mathrm{ve}$ & $-\mathrm{ve}$ & $40 \%$ \\
\hline hylA & -ve & $+\mathrm{ve}$ & $+\mathrm{ve}$ & -ve & $50 \%$ & $+\mathrm{ve}$ & -ve & $+\mathrm{ve}$ & $-\mathrm{ve}$ & $-\mathrm{ve}$ & $40 \%$ \\
\hline
\end{tabular}

$\mathrm{P} 1=$ First patient

$\mathrm{P} 2=$ Second patient 
(1)

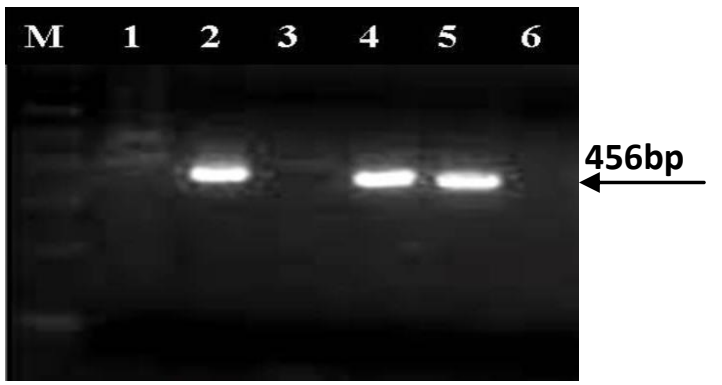

(2)



Figure (1): Agarose gel electrophoresis of PCR amplification products using specific listeriolysin gene ( $h l y A$ primers) of L.monocytogenes isolated from eggs. Lane M: 100 bp ladder as molecular DNA marker, Lane 1: Control negative, Lane 2: Control positive, Lane 3 and Lane 6: Negative L.monocytogenes for listeriolysin production, Lane 4 and Lane 5: Positive L.monocytogenes for listeriolysin production.

Figure (2): Agarose gel electrophoresis of PCR amplification products using specific primers of InlA gene of L.monocytogenes isolated from eggs. Lane M: 100 bp ladder as molecular DNA marker, Lane 1: Control positive for InlA gene, Lane 6: Control negative, Lane 2, Lane 3, Lane 4 and Lane 5: Positive L.monocytogenes for InlA gene.

(3)



(4)



Figure (3): Agarose gel electrophoresis of PCR amplification products using specific listeriolysin gene ( $h l y A$ primers) of L.monocytogenes isolated from clinical human samples. Lane M: 100 bp ladder as molecular DNA marker, Lane 1: Control negative, Lane 2: Control positive, Lane 3, Lane 4 and lane 6: Negative L.monocytogenes for listeriolysin production, Lane 5 and Lane 7: Positive L.monocytogenes for listeriolysin production.

Figure 4: Agarose gel electrophoresis of PCR amplification products using specific primers of InlA gene of L.monocytogenes isolated from clinical human samples. Lane M: 100 bp ladder as molecular DNA marker, Lane 1: Control positive for InlA gene, Lane 7: Control negative, Lane 3 and Lane 4: Positive L.monocytogenes for InlA gene, Lane 2, Lane 5 and lane 6: Negative L.monocytogenes for InlA gene.

\section{DISCUSSION}

The microbiological and biochemical analysis of 30 pooled egg samples in the present study revealed failure of detection of L. monocytogenes from all egg contents samples (Table 1), this result goes parallel with that of Saad and El-Prince (1995); Korashy et al. (2008); Sayed et al. (2009); Ghasemian-Safaei et al. (2011) and Namish (2011). Absence of $L$. monocytogenes in egg contents may be attributed to the unsuitability of $\mathrm{pH}$ of raw egg albumen for growth of L. monocytogenes. Furthermore, presences of antibacterial properties of eggs which hydrolyze the polysaccaride bacterial cell wall causing cell lysis (Yadava and Vadehra, 1977). Table 1 showed that the occurrence of L. monocytogenes in the egg shells samples was $4(13.3 \%)$ which is lower than the result of Saad and El-Prince (1995) (17.7\%) and Jones et al. (2004) (18.3\%) and higher than Sayed et al. (2009) (7\%). While, each of Korashy et al. (2008) and Ghasemian -Safaei et al. (2011) failed to isolate $L$. monocytogenes from the examined egg shells samples. Regarding the increasing consumption of egg and its products, it is necessary to investigate egg contamination with $L$. monocytogenes as it is very frequently present in broiler poultry farms and flocks of laying hens (Chemaly et al., 2008), the egg shell 
contamination may be resulted from deposition of fecal material on the shell, ovarian or oviduct and gut flora, egg crates, packing and storage, clothes and hands of poultry workers, dust, transporting and marketing (De Reu et al., 2006).

About one-third of reported human listeriosis cases happen during pregnancy, which may result in spontaneous abortion in second or third trimester (CDC, 2005). In the present study, the microbiological and biochemical analysis of 120 samples from 30 patients with a history of spontaneous abortions revealed $5(4.2 \%)$ isolates resembling L. monocytogenes; two samples (6.6\%) from amniotic fluid, two samples $(6.6 \%)$ from vaginal swabs and one $(3.3 \%)$ urine sample, while did not recover from stool samples (Table 2). In contrast, Dhanashree et al. (2003) could not isolate $L$. monocytogenes from amniotic fluids. However, Hanan (1994); Asmaa (1998); Kaur et al. (2007); Stepanovic et al. (2007); Namish (2011) and harmendra et al. (2013) reported lower results of positive infection of $L$. monocytogenes in vaginal swabs $2.08 \%, 3.3 \%, 1.6 \%, 0.1 \%, 2 \%$ and $1.3 \%$ respectively. In contrast higher results (10\%) in vaginal swabs were recorded by Stephen et al. (1978). Kaur et al. (2007) showed that $1.6 \%$ of urine samples were infected with $L$. monocytogenes, while $0 \%$ from stool samples as well as Dhanashree et al. (2003).

Lamont et al. (2011) illustrated that $L$. monocytogenes is an intracellular pathogen which, following ingestion of contaminated food, is phagocytosed and internalised in epithelial cells by the interaction between the bacterial surface protein, internalin (inlA), and its receptor on the epithelial surface (E-cadherin.). The organism is vacuolated by macrophages, polymorphonuclear leucocytes and other plasma cells, and escapes the vacuole through the action of listeriolysin $(h l y A)$, finally entering the cytoplasm where proliferation occurs. So; several polymerase chain reaction systems (PCR) for the detection of L. monocytogenes have been described, mainly targeting the virulence genes such as those encoding the inlA and $h l y A$ (Dharmendra et al., 2013). However, it is plausible that some L.monocytogenes strain may lack one or more virulence determinants because of some mutation (Cooray et al., 1994). Using PCR assay for detection of single virulence associated gene is neither sufficient to identify the L. monocytogenes isolates nor to reveal its true pathogenic potential as majority of L. monocytogenes isolates showed different gene profiles (Rawool et al., 2007).

Results illustrated in Table 3, figure 1 and figure 2 revealed that all four $(100 \%)$ isolates of $L$. monocytogenes isolated from the examined egg shell samples were found to harbor inlA gene, while 2
(50\%) of them posses hlyA gene. In contrast, Namish (2011) failed to detect inlA gene in L. monocytogenes isolated from examined egg shell samples. Jacquet et al. (2004) and Roche et al. (2009) stated that some isolates of L. monocytogenes isolated from different raw and ready to eat food were harbor inlA gene with or without $h l y A$ gene which supported the usefulness of studying the pathogenic potential of strains that contaminate the food supply.

Table3, figure 3 and figure 4 shows that two out of five L. monocytogenes strains isolated from the clinical human samples posses virulence genes (from amniotic fluid and vaginal swabs) which recovered from one patient. Each of two strains were associated with both inlA and $h l y A$ virulence genes, which confirm the finding that internalin and listeriolysin are highly associated with clinical strains which support their critical role in human listeriosis (Lamont et al., 2011). Burtun and Blais (2006) and Dharmendra (2013) found that inlA and hlyA virulence genes were represented in each of clinical human samples and food samples. Moreover, the presence or absences of some virulence genes are good indicators of the level of virulence of Listeria strains (liu et al., 2007). The current study also reveals that internalin and listeriolysin can be used as biomarkers for stratifying the virulence of strains recovered from food surveillance program.

\section{REFERENCES}

Allerberger, F. (2003): Listeria growth, phenotypic differentiation and molecular microbiology. FEMS Immunology and Medical Microbiology, 35: 183-189.

Almeida, P. and Almeida, R. (2000): A PCR protocol using inlA gene as a target for specific detection of Listeria monocytogenes. Food Control, 11: 97-101.

Asmaa, A.A.H. (1998): Listeria species in some cases associated with gynecological problems in women. Assiut Vet. Med. J., 39(78): 109-116.

Becker, B.; Schuler, S.; Lohneis, M.; Sabrowski, A.; Curtis, G.D. and Holzapfel, W.H. (2006): Comparison of two chromogenic media for the detection of Listeria monocytogenes with the plating media recommended by EN/DIN 11290-1. Int. J. Food Microbiol., 109: 127-131.

Burtun, W. and Blais, M. (2006): Identification of presumptive positive Listeria monocytogenes from food and environmental samples by the polymerase chain reaction (PCR). Health Canada, Food and Nutrition, 3: 22-27.

CDC (2005): Listeriosis. Coordinating Center for Infectious Diseases / Division of Bacterial and Mycotic Diseases, Centre for Disease Control and Prevention, Atlanta, GA 30033. Available at: $\quad$ http://www.cdc.gov/ncidod/dbmd/ 
diseaseinfo/ listeriosis_g.htm\#greatrisk. (Assessed on 20 November, 2006).

Chemaly, M.; Toquin, M.T.; Le Nôtre, Y. and Fravalo, P. (2008): Prevalence of Listeria monocytogenes in poultry production in France. J. Food Prot., 71(10): 1996-2000.

Cooray, K.J.; Nishibori, T.; Xiong, H.; Matsuyama, T.; Fujita, M. and Mitsuyama, M. (1994): Detection of multiple virulence-associated genes of Listeria monocytogenes by PCR in artificially contaminated milk samples. Appl. Environ. Microbiol., 60: 3023-3026.

Curtis, G.; Mitchell, R.; King, A. and Griffin, E. (1989): A selective differential medium for the isolation of Listeria monocytogenes. Lett. Appl. Microbiol., 8: 95-98.

De Reu, K.; Grijspeerdt, K. and Messens, W. (2006): Egg shell factors influencing egg shell penetration and whole egg contamination by different bacteria, including Salmonella enteritidis. Int. J. Food Microbiol. 112: 253-60.

Dhanashree, B.; Otta, S.K.; Karunasagar, I.; Goebel, W. and Karunasagar, I. (2003): Incidence of Listeria spp. in clinical and food samples in Mangalore. India. Food Microbiol., 20: 447- 453.

Dharmendra, K.; Soni, A.; Rakesh, K.; Singh, B.; Durg, V.; Singh, B. and Suresh, K. (2013): Characterization of Listeria monocytogenes isolated from Ganges water, human clinical and milk samples at Varanasi. India. Infection, Genetics and Evolution, 14: 83-91.

Filiousis, G.; Anders, J.; Joachim, F. and Vincent, P. (2009): Food control short communication: prevalence, genetic diversity and antimicrobial susceptibility of Listeria monocytogenes isolated from open-air food markets in Greece. Food Control, 21: 708-713.

Furrer, B.; Candrian, U.; Hoefelein, C. and Luethy, J. (1991): Detection and identification of Listeria monocytogenes in cooked sausage products and in milk by in vitro amplification of haemolysin gene fragments. J. Appl. Bacteriol., 70: 372-379.

Ghasemian Safei, H.; Jalali, M.; Hosseini, A.; Narimani, T.; Sharifzadeh, A. and Raheimi, E. (2011): The prevalence of bacterial contamination of table eggs from retails markets by Salmonella spp., Listeria monocytogenes, Campylobacter jejuni and Escherichia coli in Shahrekord, Iran. Jundishapur Jornal of Microbiology, 4(4): 249-253.

Hanan, A.N. (1994): Listeria monocytogenes infection in newborn. Ph.D., thesis, Pediatric department, Faculty of Medicine, Assiut Univerisity.

Hitchins, A.D. (1995): Listeria monocytogenes. In $8^{\text {th }}$ ed. Food and drug administration.
Bacteriological Analytical Manual. AOAC international Pub.Co., Gaithersburg, MD, USA.

Hof, H. (2003): History and epidemiology of listeriosis. FEMS Immunology and Medical Microbiology, 35: 199-202.

Ivanek, R.; Gröhn, Y. and Wiedmann, M. (2006): Listeria monocytogenes in multiple habitats and host populations: review of available data for mathematical modeling. J. Food borne pathogens and Diseases, 3: 319-336.

Jacqute, C.; Doumith, M.; Gordon, J.; Martin, P.; Cossart, P. and Lecuit, M. (2004): A molocular marker for evaluating the pathogenic potential of food borne Listeria monocyogenes. JID, 189: 2094-2100.

Jamali, H.; Chai, L. and Thong, K. (2013): Detection and isolation of Listeria spp. and Listeria monocytogenes in ready-to-eat foods with various selective culture media. Food Control, 32: $19-24$.

Jeyaletchumi, P.; Tunung, R.; Margaret, S.P.; Son, R.; Farinazleen, M.G. and Cheah, Y.k. (2010): Detection of Listeria monocytogenes in foods. Int. Food Res. J., 17: 1-11.

Jones, D.R.; Curtis, P.A.; Anderson, K.E. and Jones, F.T. (2004): Microbiological contamination in inoculated shell eggs: II. Effects of layer strain and egg storage. Poult. Sci., 83: 95-100.

Kaur, S.; Malik, S.; Vaidya, V. and Barbuddhe, S. (2007): Listeria monocytogenes in spontaneous abortions in humans and its detection by multiplex PCR. J. Appl. Microbiol. 103: 1889-1896.

Korashy, Eman; Wahba, Nahed and Hassanein, R. (2008): Public health hazards of some bacterial pathogens associated with consumption of eggs and studying the best cooking methods for their destruction. Assiut Vet. Med. J.54: 59-77.

Lamont, F.; Frcog1, C.; Sobel, J.; Mazaki-Tovi, S.; Kusanovic, J.; Vaisbuch, E.; Kwon Kim, S.; Uldbjerg, N. and Romero, R. (2011): Listeriosis in Human Pregnancy: a systematic review. J. Perinatal Medicine, 39(3): 227-236.

Liu, D.; Lawrence, M.L.; Austin, F.W. and Ainsworth, A.J. (2007): A multiplex PCR for species and virulence-specific determination of Listeria monocytogenes. J. Microbiol. Meth., 71(2): 133-140.

Moats, W.A. (1980): Classification of bacteria from commercial egg washers and washed and unwashed eggs. J. Appl. Environ. Microbiol., 4: 710-714.

Namish, M. (2011): Occurrence of listeria monocytogenes in poultry and its public health hazards on women. M.V.sc., thesis. Faculty of Vet. Medicine, Assiut University.

Nishibori, T.; Cooray, K.; Xiong, H.; Kawamuru, I.; Fujita, M. and Mitsuyama, M. (1995): 
Correlation between the presence of virulence associated genes as determined by PCR and actual virulence to mice in various strains of Listeria spp. Microbiol Immunol.,39: 343-349.

Notermans, S.; Dufrenne, J.; Leimeister-Wachter, M.; Domann, E. and Chakraborty, T. (1991): Phosphatidylinositol-specific phospholipase C activity as a marker to distinguish between pathogenic and non-pathogenic Listeria species. Appl. Environ. Microbiol., 57: 2666-2670.

Pesavento, G.; Ducci, B.; Nieri, D.; Comodo, N. and Lo Nostro, A. (2010): Prevalence and antibiotic susceptibility of Listeria spp. isolated from raw meat and retail foods. Food Control, 21(5): 708-713.

Portnoy, D.A.; Ghakraborty, T.; Goebel, W. and Cossart, P. (1992): Molecular determinants of Listeria monocytogenes pathogenesis. Infect. Immun., 60: 1263-1267.

Rawool, D.B.; Malik, S.V.S.; Barbuddhe, S.B.; Shakuntala, I. and Aurora, R. (2007): A multiplex PCR for detection of virulence associated genes in Listeria monocytogenes. Int. J. Food Safety, 9: 56-62.

Roche, S.; Kerouanton, A.; Minet, J.; Le Monnier, A.; Brisabois, A. and Velge, P. (2009): Prevalence of low virulence Listeria monocytogenes strains from different foods and environments. Int. J. Food Microbiol., 130(2): 151-155.

Rocourt, J.; Jacquet, C. and Reilly, A. (2000): Epidemiology of human listeriosis and seafood. Int. J. Food Microbiol., 62: 197-209.

Ryser, E.T. and Marth, E.H. (2007): Listeria, listeriosis and food safety (3rd ed.). Taylor and Francis, CRC Press.

Saad, Nagah M. and El-Prince, Enas (1995): Prevalence of Listeria species in hen's eggs sold in Assiut city. Assiut Vet. Med. J.33: 127-131.
Sayed, M.; Abdel-Azeem, M.; Farghaly, M. and Hassanein, R. (2009): Using of PCR assay for identification of Listeria monocytogenes recovered from table eggs. Veterinary World, 2(12): 453-455.

Shi, W.; Qingping, W.; Jumei, Z.; Moutong, C. and Zéan, Y. (2015): Prevalence, antibiotic resistance and genetic diversity of Listeria monocytogenes isolated from retail ready-toeat foods in China. Food Control, 47: 340-347.

Speck, M.L. (1976): Compendium of methods for the microbiological examination of foods. American Public Health Association, Washington, D.C.

Stepanovic, S.; Vukovih, D.; Djukih, S.; Hirkovih, I. and Svabih-Vlahovih, M. (2007): Long-term analysis of Listeria monocytogenes vaginal carriage frequency in Belgrade, Serbia. Acta Microbiologica et Immunologica Hungarica, 54 (2): 195-199.

Stephen, S.; Indrani, R.; Achyutha Rao, K. and Padma Rao, A. (1978): Listeriosis and human abortions including a brief review of literature. J. Obstet. Gynaecol. India XXVIII No. 4: 497-501.

Yadava, N.K. and Vadehra. D.V. (1977): Mechanism of egg white resistance to bacterial growth. J. Food Sci., 42 (1): 97-99.

Yucel, N.; Citak, S. and Onder, M. (2005): Short communication: prevalence and antibiotic resistance of Listeria species in meat products in Ankara, Turkey. Food Microbiol., 22: 241-245.

Zhou, X. and Jiao, X. (2004): Investigation of Listeria monocytogenes contamination pattern in local Chinese food market and the tracing of two clinical isolates by RAPD analysis. Food Microbiol., 21: 695-702.

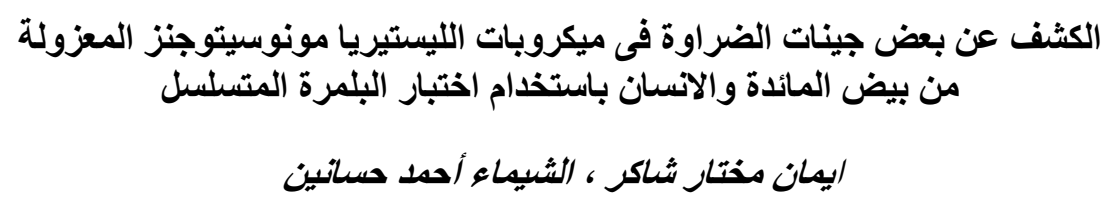

Email: hassanien2008@yahoo.com

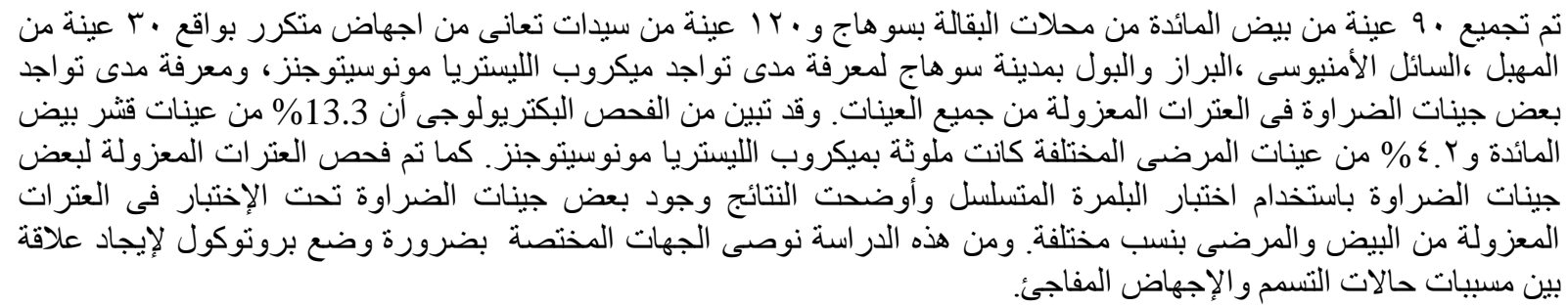

